\title{
$\mathrm{AE}$ 信号を利用した砥石摩耗に基づく 工作物形状誤差の間接測定と先の補正*
}

\author{
和 泉 真 澄*1, 李 和 樹*2 \\ 若林忠*2, 井上茂*3
}

\section{Measurement of Workpiece Form Errors due to Wheel Wear Using AE Signals and their Compensation in Grinding}

\author{
Masumi IZUMI, Hwa-Soo LEE, \\ Tadashi WAKABAYASHI and Shigeru INOUE
}

\begin{abstract}
In this study, a method to measure workpiece form errors due to the grinding wheel wear for NC grinding machines and their compensating method are proposed. In this method, the contact between a wheel and a dresser is monitored from AE signals during dressing process with a dresser with the $\mathrm{AE}$ sensor, and maximum wheel profile wears are measured from the dresser depth obtained NC programs. Workpiece form errors are measured from the relationships between wheel wears and workpiece form errors, and then workpiece form errors are compensated by repeating grinding until the workpiece form error to be less than desired tolerance. As the experimental results, it is confirmed that workpiece form errors can be measured by the AE signals after grinding accurately. Furthermore, it is shown that the compensating method proposed in this study can be used in actual grinding operations.
\end{abstract}

Key Words : Dressing, Acoustic Emission Sensor, Workpiece Form Error, Measurement, Compensation, Maximum Wheel Profile Wear

\section{1 。緒言}

研削加工の進行にともなって砥石の作業面は摩耗し 後退する．ＮC研削盤を用いた研削加工において高い 加工精度を得るためには予め加工において発生する作 業面の後退量を補正する必要がある。このためには加 工に先立って砥石の摩耗量を定量的に予測する必要が あるが, 工作物の形状, 材質ならびに加工量が一定で ある場合をのぞくとこれを定量化することは困難であ る.また，要求される加工精度が厳しくなっている昨 今では, 加工途中において工作物を直接測定しなけれ ばならず，これが研削加工を無人化する上で解決しな ければならない大きな問題の一つとなっている。

前報では平面研削加工において砥石摩耗により発生 した工作物の寸法誤差を砥石半径摩耗から測定し, 工 作物寸法誤差を自動的に補正するサイクルを提案して その有用性を確認した 1 ).

本研究では, 総形研削加工において砥石摩耗に基づ き発生する工作物の形状誤差に着目し, 研削加工後の 形状誤差を機上で間接測定して自動的に補正加工を行 わせるサイクルを提案するものである。

* 原稿受付 1998 年 1 月 16 日。

*1 正員, 日本大学大学院(画 101-8308 東京都千代田区神田駿河 台 1-8-14)

*2 正員, 日本大学理工学部.

*3 牧野フライス精機(株) (画 243-0303 神奈川県愛甲郡愛川町 中津 4029).
本方法では $\mathrm{AE}$ センサをドレッサに取付けて加工後の 砥石を目直しして得られる $\mathrm{AE}$ 信号から砥石とドレッサ の接触をとらえ，それと NC プログラムより与えられる ドレッサの切込み量から最大砥石輪郭摩耗量を测定し ている、そして, 最大砥石輪郭摩耗量と工作物形状誤 差の関係に基づいて工作物の形状誤差を間接測定し， この形状誤差が所望の公差内におさまるまで繰り返し 研削加工を行い形状誤差を補正している。これらの方 法の有用性を確認したので報告する.

\section{2 、実験装置および方法}

図 1 に実験装置の概略図を示す。本実験は NC 立軸フ ライス盤を用いて行った。NC フライス盤のスピンドル には砥石を取り付け，テーブル上には垂直マグネット・ チャックとドレッシング装置を配置し，研削加工を行 える状態にしている。ドレッシング装置はパーソナル。 コンピュータにより B 軸回りの位置決めが可能である. 砥石の切込みはテーブルのX軸の移動によって与え目 直し時の砥石軸方向の送りは砥石ヘッドの Z 軸の運動 によって, 研削中の工作物の送り運動はテーブルのY 軸方向の運動によって与えている，以下，本実験で用 いた NCフライス盤を NC 研削盤と称す。

$\mathrm{AE}$ センサは単石ドレッサの後端部に取り付けられて おり，目直し時の砥石とドレッサの接触信号をとらえ ている. $\mathrm{AE}$ センサからの信号は $26 \mathrm{~dB}$ 增幅され，折点周 


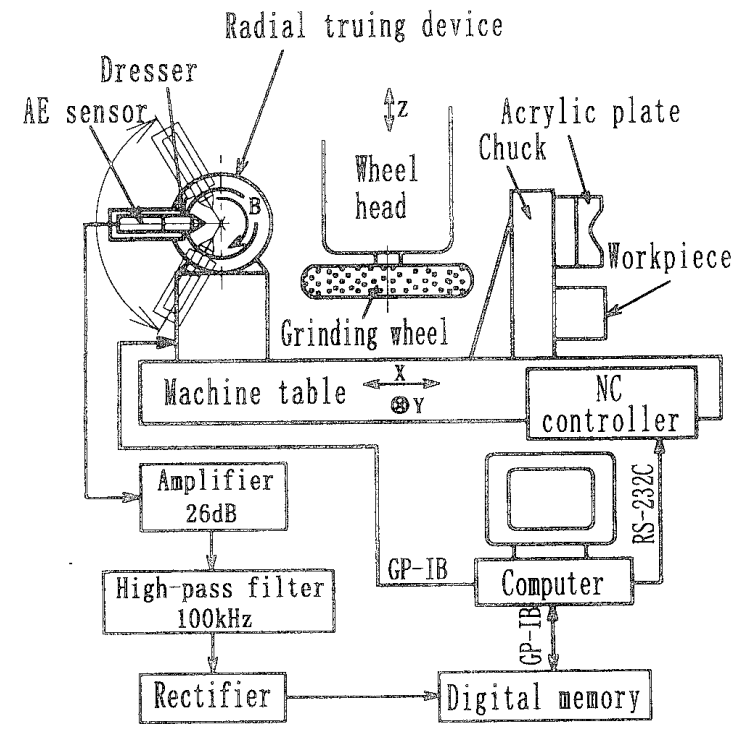

Fig. 1 Schematic diagram of experimental set-up

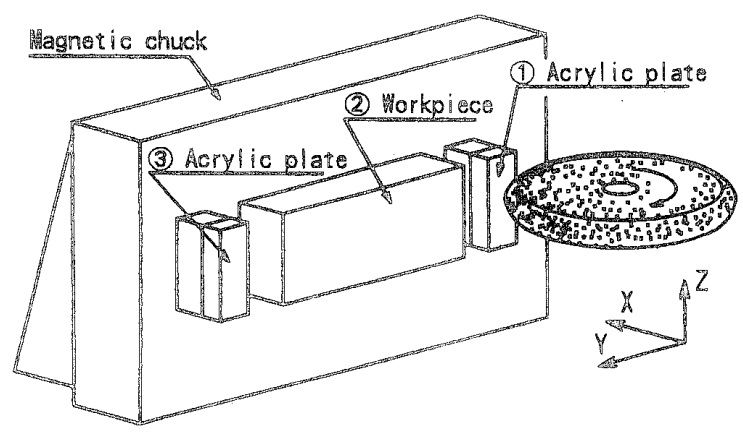

Fig.2 Workpiece loaded on a chuck

波数 $100 \mathrm{kHz}$ のハイパス・フィルタを通過し，半波整流 された電压信号となり，デジタルメモリを介してパー ソカル。コンピュータに取り込み观理した。このよう に処理した信号はAE アベレージ信号と呼ばれ，AE源信 号の平均的な振幅レベルを表わすことになる。以下 AE アベレージ信号を AE 信号と称す。なお，本実験では共 振周波数 $140 \mathrm{kHz}$ (エヌエフ回路設計ブロック社製，型 武: $A E-901 S)$ の $A E$ センサを使用している。

図2に工作物の取何け状態を示す。本実験では以下 の手順で研削加工を行った。図のように工作物とアク リル樹脂枋を直列に並ベワンパス研削した。(1)のアク リル樹脂材には研削加工前の砥石輪郭形状が転写され， (2)の工作物を研削した後の砥石輪郭形状が(3)のアクリル 澍脂材に転写される。加工後に(1)と(3)のアクリル樹脂材 の形状を触剑式輸郭形状測定機を用いて測定し, 研削 加工後の䃌石輪郭摩㘪量を測定した。また，(1)と(2)の形 状の差を測定するるとにより加工前の砥石輪郭形状を 基準とした工作物形状䛊差を求めた。本研究において， 磁石輪郭摩耗量とは摩耗による砥石輪郭形状の変化量
Table 1 Machining conditions

\begin{tabular}{l|c|c}
\hline Grinding process & $\begin{array}{c}\text { Circular groove } \\
\text { grinding }\end{array}$ & V groove grinding \\
\hline Profile of wheel & Radius $=25 \mathrm{~mm}$ & V angle $=160^{\circ}$ \\
\hline Grinding wheel & \multicolumn{2}{|c}{ WA46G8V $(\phi 205 \times 20 \mathrm{~mm})$} \\
\hline Workpiece & \multicolumn{2}{|c|}{ SKD $11(60 \times 40 \mathrm{~mm}, \mathrm{HRC} 63)$} \\
\hline Wheel speed & \multicolumn{2}{|c}{$1800 \mathrm{~m} / \mathrm{min}$} \\
\hline Table speed & \multicolumn{2}{|c}{$30 \mathrm{~mm} / \mathrm{min}$} \\
\hline Wheel depth of cut & $400 \mu \mathrm{m}$ & $600 \mu \mathrm{m}$ \\
\hline Dressing & \multicolumn{2}{|c|}{$10 \mu \mathrm{m} \times 10 \mathrm{pass}(0.2 \mathrm{~mm} / \mathrm{rev}) ;$} \\
& $5 \mu \mathrm{m} \times 5 \mathrm{pass}(0.1 \mathrm{~mm} / \mathrm{rev}) ;$ \\
\hline Coolant & $0 \mu \mathrm{m} \times 5 \mathrm{pass}(0.05 \mathrm{~mm} / \mathrm{rev})$ \\
\hline
\end{tabular}

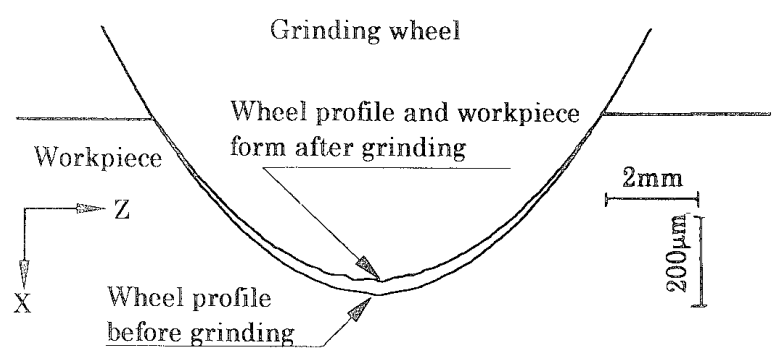

Fig.3 Wheel profiles and workpiece form in circular grinding

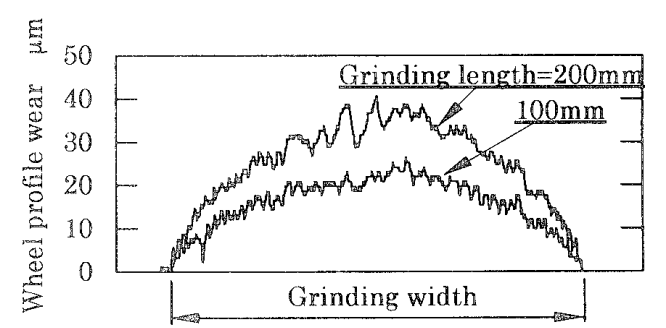

Fig.4 Wheel profile wears with grinding length

を示し，その变化量の最大值を最大砥石輪郭摩耗量と 定義する。

本寒験で用いた加工条件は表 1 の通りである。

\section{3。最大砥石輸郭摩耗量の测定}

3.1 丸漖研削の場合図 3 は丸溝研削加工にお いて図 2 のように配置した工作物とアクリル樹脂材を 研削し，それらの形状を测定して重ねあわせて示した ものである。この研削では研削距離を200mm としてい る。この悩に示されたように，砥石は研削後には大き く摩耗しており工作物には形状誤差が生じていること が分かる。

図 4 は，圆 3 における研削加工で研削距離が $100 \mathrm{~mm}$

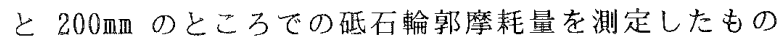
である。この図より，砥石輪郭摩耗量は研削距離とと もに增加して仂き，研削距離 $200 \mathrm{~mm}$ すなわち工作物終 端部に達したところで砥石輪郭摩耗量の最大值が約 40 佃であった。 


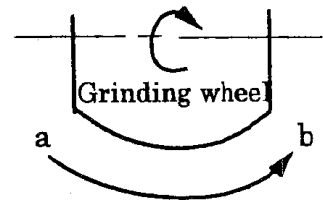

(b) Dressing manner

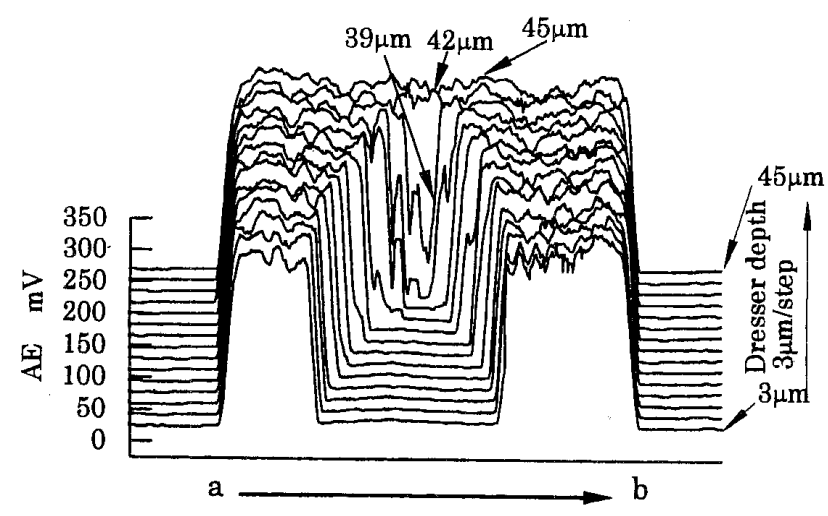

Fig.5(a) AE signals in dressing

図 5 (a)は図 3 に示した研削後の砥石を $\mathrm{AE}$ センサ付 きドレッサでドレッサの切込み量を砥石半径方向に 3 $\mu \mathrm{m}$ とし, 図 5 (b)に示した方法で逐次目直しして得た $\mathrm{AE}$ 信号を切込み順に並べて示したものである.目直し 中の砥石とドレッサの干渉によりドレッサ後端部に取 付けられた $\mathrm{AE}$ センサから電圧信号が出力され, 砥石と ドレッサの接触の有無が明瞭に表れている.ドレッサ 累積切込み量が $3 \mu \mathrm{m}$ の時の $\mathrm{AE}$ 信号は砥石幅中央部に おいて AE 信号のレベルが低くこの部分で砥石とドレッ サが接触していないことが分かる.ドレッサ累積切込 み量が増すとともに砥石幅中央部のレベルの低い非接 触部分が減少し, ドレッサ累積切込み量が $42 \mu \mathrm{m}$ 以上 では砥石幅全体にわたって一様なレベルの $\mathrm{AE}$ 信号が表 れている.これらの $\mathrm{AE}$ 信号からも, 図 3 および図 4 に 示したように砥石先端部ほど砥石が大きく摩耗してい ることが確認できる.

$\mathrm{AE}$ センサ付きドレッサを用いて加工後の砥石を目直 しして得られる $\mathrm{AE}$ 信号より, 本研究では以下のように して最大砥石輪郭摩耗量を測定した。図 6 に図 5 (a)で 示したドレッサ切込み量が $39 \mu \mathrm{m} と 42 \mu \mathrm{m}$ の時の $\mathrm{AE}$ 信 号と, 砥石とドレッサの接触の有無を判定するために 研削加工前の仕上げ目直し時で得た $\mathrm{AE}$ 信号をしきい值 の信号としてそれぞれを重ねて示す。ドレッサの切込 み量をゼロとして行う仕上げ目直しでは，砥石とドレ ッサが微小な接触状態にあり，この接触状態から得ら れる $\mathrm{AE}$ 信号のレベルを基準にして砥石とドレッサの接 触を判定することが可能である1). 本研究では前報と 同様に仕上げ目直し時の A E 信号波形をしきい值とし

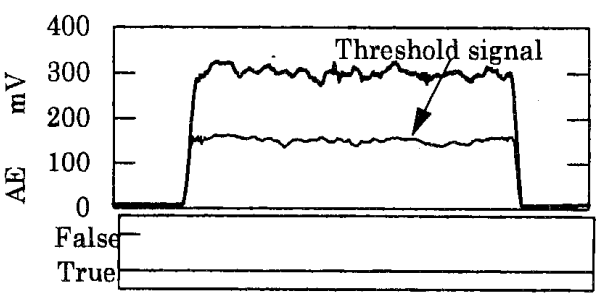

(b) $42 \mu \mathrm{m}$

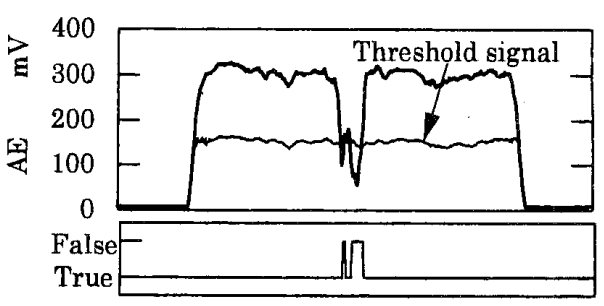

(a) $39 \mu \mathrm{m}$

Fig.6 Comparison of $\mathrm{AE}$ signals
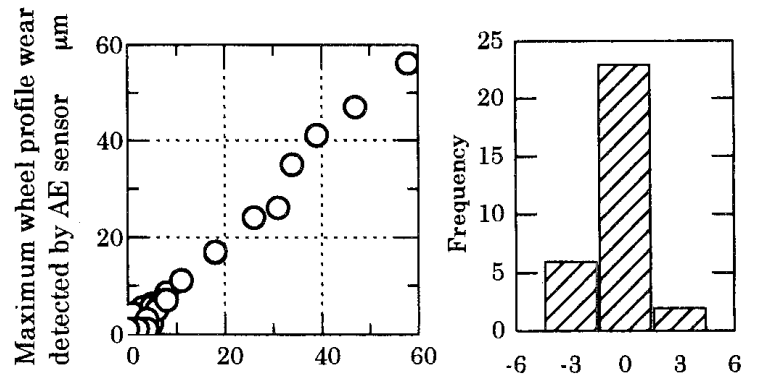

Maximum wheel profile wear $\mu \mathrm{m} \quad$ Measuring error $\mu \mathrm{m}$

(a) Maximum wheel profile wears detected by $\mathrm{AE}$ sensor

(b) Measuring error of the present method

Fig. 7 Comparison between actual amount of maximum profile wear and measured value by AE signals in circular groove grinding

て用い,これを加工後の目直し時に得られた A E 信号 と比較している。

図 6 （a）のドレッサ切込み量が $39 \mu$ 円 の場合では， 砥石先端部で $\mathrm{AE}$ 信号のレベルがしきい值信号のレベル よりも小さい部分があり，この部分で砥石とドレッサ が接触していないと考えられる．同図(a)の下の図は $\mathrm{AE}$ 信号のレベルがしきい值信号のレベルより小さいとき False を示し, それ以上の場合は True として示したも のである、この図からもドレッサが砥石先端部で接触 していないことが確認できる.一方，図（b)では， $\mathrm{AE}$ 信号は砥石幅全体にわたってしきい值信号を越えてお り，True のレベルを示していることからドレッサは砥 石幅全体にわたつて接触していることが確認できる。 これらのことより, 目直し時の $\mathrm{AE}$ 信号から最大砥石輪 郭摩耗量は $39 \mu \mathrm{m}$ を超え $42 \mu \mathrm{m}$ 以下であると判定される。 この結果は図 4 で示した砥石輪郭摩耗量の最大值 $40 \mu \mathrm{m}$ 
Grinding wheel

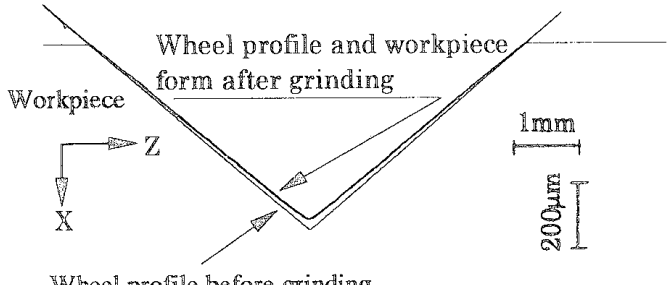

Wheel profile before grinding

Fig.8 Wheel profiles and workpiece form in $\mathrm{V}$ groove grinding

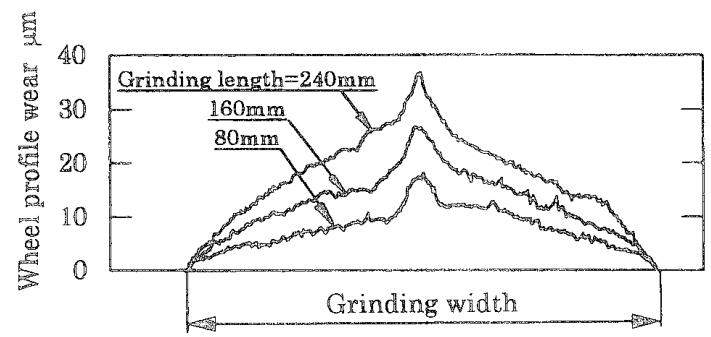

Fig.9 Wheel profile wears with grinding length

\section{とよく一致している。}

図7は研削加工後の最大砥石輪郭摩耗量を AE 信号か ら測定した結果である。図( ( ) より, 最大砥石輪郭摩 耗量を広い範囲にわたって精度よく測定できることが 分かる。同図（b）は(a)の測定誤差を示したものであ る。この図より本方法は最大砥石輪郭摩耗量の測定䛊 差が士 $3 \mu$ 且以内であった。これは，本実験に使用した NCフライス盤の位置決わ精度を考慮してドレッサの切 込み量を 3 从皿として行っていることによるもので测定 分解能はこれに従って3ル四となっており，使用するNC 研削盤の精度に応じた分解能が得られたものと考えら れる。

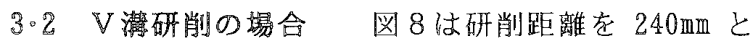
設定しV 嗨研削加工を行った後の砥石輪郭形状と工作 物形状を測定した結果である。この図においても前述 の如瑇研削の場合と同様に，研削後の砥石には摩耗が 生じており。工作物には形状誤差が生じている。

図9 は図8に示した研削加工で，研削距離が $80,160,240$ m $の$ 各距離に達した時の砥石輪郭摩耗量を 測定した結果である。この図より，砥石輪郭摩耗量は 砥石幅の中央部で大きく，研削距離の增加とともに増 加している。また，研削距離が $240 \mathrm{~mm}$ すなわち工作物 終端部に達したところで砥石輪郭摩耗量の最大值が 37 讯であった。

㘣 10 (b)は同図(a)に示したようにドレッサを送り，

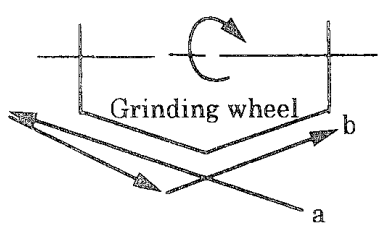

(a) Dressing manner

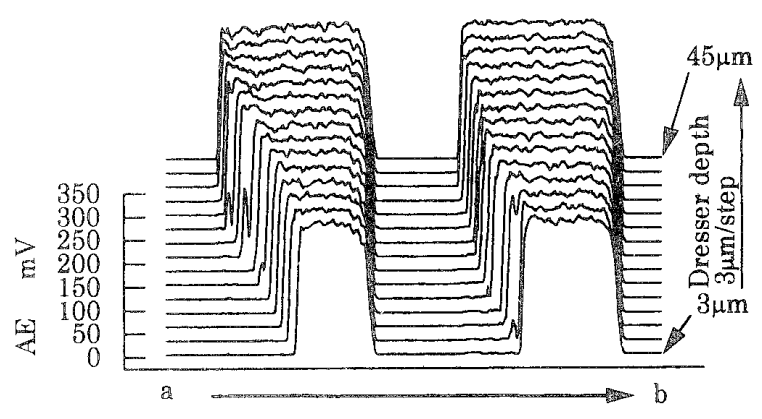

Fig. 10(b) AE signals in dressing

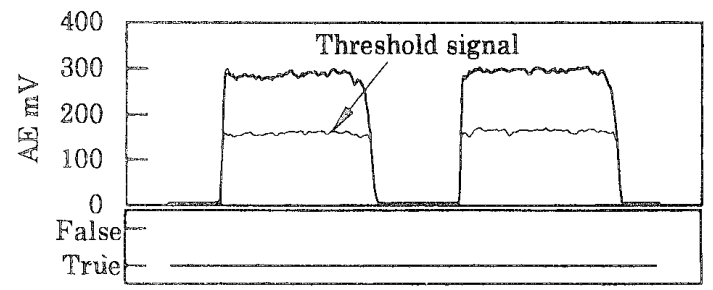

(b) $39 \mu \mathrm{m}$

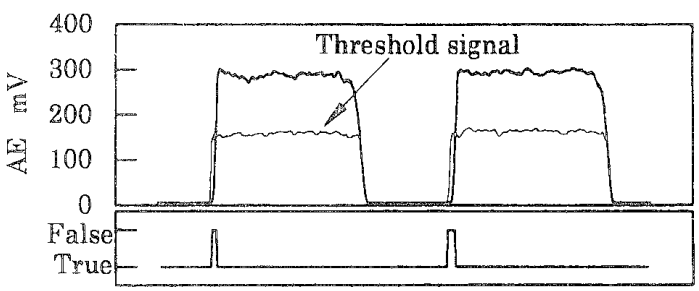

(a) $36 \mu \mathrm{m}$

Fig.11 Comparison of AE signals

図 8 に示した研削後の砥石を $A E$ センサ付きドレッサで 目直しして得た $A E$ 信号である。同図(b)より，ドレッ 妙累積切込み量の増加にしたがって $\mathrm{AE}$ 信号は一定のド レス長さを表す形状を示している。これは砥石先端部 が最も摩耗していたため，ドレッサ累積切込み量が小 さいほどドレッサと砥石の接触開始時期が遅れ，ドレ ッサ紫積切込み量の増加とともにドレス長さが徐々に 增加したためである。

これらの $\mathrm{AE}$ 信号より。丸溝研削加工と同様に最大砥 石輪郭摩耗量を測定した。図 10(b)のドレッサ累積切込 み量が $36 \mu \mathrm{m} と 39 \mu \mathrm{m}$ の $\mathrm{AE}$ 信号とここの研削加工前の 任上げ目直しで得たしきい值信号とを図 11 に示す。 


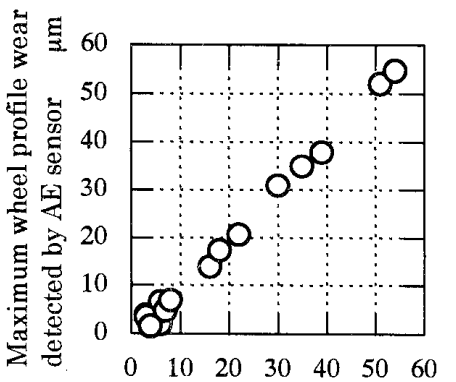

Maximum wheel profile wear $\mu \mathrm{m}$

(a) Maximum wheel profile wears detected by $\mathrm{AE}$ sensor

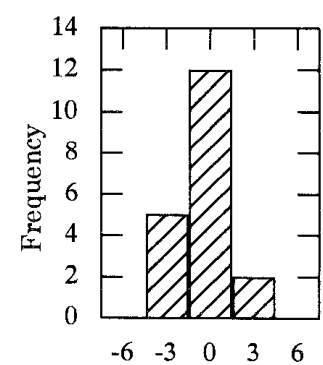

Measuring error $\mu \mathrm{m}$ the present method (b) Measuring error of

Fig.12 Comparison between actual amount of maximum wheel profile wear and measured value by $\mathrm{AE}$ signals in $\mathrm{V}$ groove grinding

図(a)のドレッサ累積切込み量が $36 \mu \mathrm{m}$ の時では, 砥石 の先端部に相当する部分で $\mathrm{AE}$ 信号はしきい值信号を下 回っている. 同図(a)の下の図では $\mathrm{AE}$ 信号がしきい值 信号を下回ったことを示すFalse のレベルが砥石先端 部に相当するところで表れている.一方, 図(b)の場合 では， $\mathrm{AE}$ 信号は砥石幅全体にわたってしきい值信号を 上回っており，同図(b)の下の図もこれと同じ結果を表 している.これらのことょり, V 溝研削加工後の最大 砥石輪郭摩耗量は $36 \mu \mathrm{m}$ を越え $39 \mu \mathrm{m}$ 以下の範囲であ ると判定できる.この結果は図 9 に示した最大砥石輪 郭摩耗量 $(37 \mu \mathrm{II})$ と一致している.

図 12 はこのようにしてV 浇研削加工後の最大砥石輪 郭摩耗量を測定した結果である。同図(a)より，本方法 は広い範囲で最大砥石輪郭摩耗量を測定できることが 分かる.一方, 図(b)は図(a)の测定䛊差を表しており, 本方法の場合の測定誤差は丸溝研削の場合と同様に土3 的であった.

\section{4. 工作物形状誤差の間接測定}

工作物形状䛊差を発生させる要因である砥石輪郭摩耗 に着目し, 研削後の最大砥石輪郭摩耗量を $\mathrm{AE}$ 信号を利 用して測定し工作物形状誤差を間接測定した。図13 は 丸溝およびV敏研削加工における工作物形状䛊差の間 接測定結果である。同図（a)より，本実験の範囲では 丸溝研削加工後の工作物形状誤差を $\pm 3 \mu \mathrm{m}$ 以内の誤差 で間接測定し得ることが確認できた。図(b)はV溝研削 加エにおける場合である。この図よりV海研削加工に おいても本方法は工作物形状誤差を $\pm 3 \mu \mathrm{m}$ 以内の誤差 で間接的に測定し得ることが確認できた。これらのこ とより加工後の最大砥石輪郭摩耗量を $\mathrm{AE}$ 信号を利用し て測定し，本実験では図 13 に示された誤差の範用内で

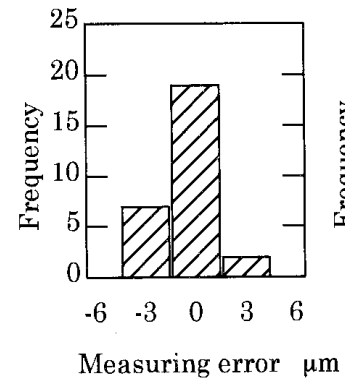

(a) Circular groove grinding

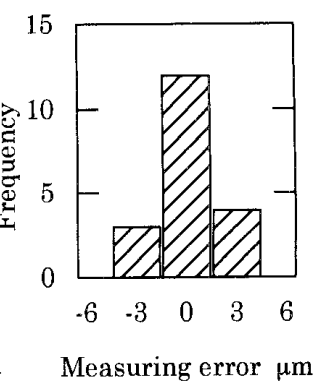

(b) $\mathrm{V}$ groove grinding
Fig.13 Measuring errors of workpiece forms

工作物の形状誤差を間接測定し得ることが確認できた。

5. 工作物形状精度補正サイクル

加工後の工作物形状誤差を機上でとらえ, 所望の形状 公差内に自動的に加工し得れば実用上有用である。本 研究では土作物形状䛊差の間接測定法を応用した簡便 な工作物形状誤差補正サイクルを提案し，これを実施 してこのサイクルの有用性を確認した。

図14は丸溝研削加工における形状誤差補正サイクル の流れ図である。本サイクルは NC 研削盤を対象として いる. 加工に必要な砥石先端半径 $R$, 碰石切込み樑さ $\mathrm{A}$, 工作物長さ $\mathrm{L}$, 所望の形状公差に対応したドレッ サ切込み量 Tの加工条件を入力し， NC プログラムを作 成する．NC研削盤はプログラムにしたがって砥石を目 直し続いて仕上げ目直しを行い，砥石とドレッサの接 触を判定するためのしきい值信号を採取する．続いて， 研削加工を実施する. 次に研削後の砥石輪郭形状より エ作物形状を評価する。ここでの評価方法は，所望の 公差に対応したドレッサ切込み量 Tで加工後の砥石を 1 パスだけ目直しして得られる $\mathrm{AE}$ 信号を採取し，この $\mathrm{AE}$ 信号としきい値信号を比較する. AE 信号のレベルが しきい值信号のレベル以上の場合，図 6(b)に示したよ うに True の結果が得られるので最大砥石輪郭摩耗量は 所望の公差以内にあり工作物形状誤差もそれ以下であ ると判定して研削作業を終了する。そうでないときは 再びドレッシングサイクルに戻りそれ以後の作業を繰 り返し行い工作物形状㕵差を自動的に補正することが できる。このような評価基準を用いることにより種種 の砥石形状にも本サイクルを大きく変更することなく 適用することが可能であると考えられる。一方，V㴖 研削の場合における形状誤差補正サイクルは丸溝研削 と同様である。

図15 は研削距離がそれぞれ異なる工作物に対して本 補正システムを実施して得た結果である.同図(a)に丸 


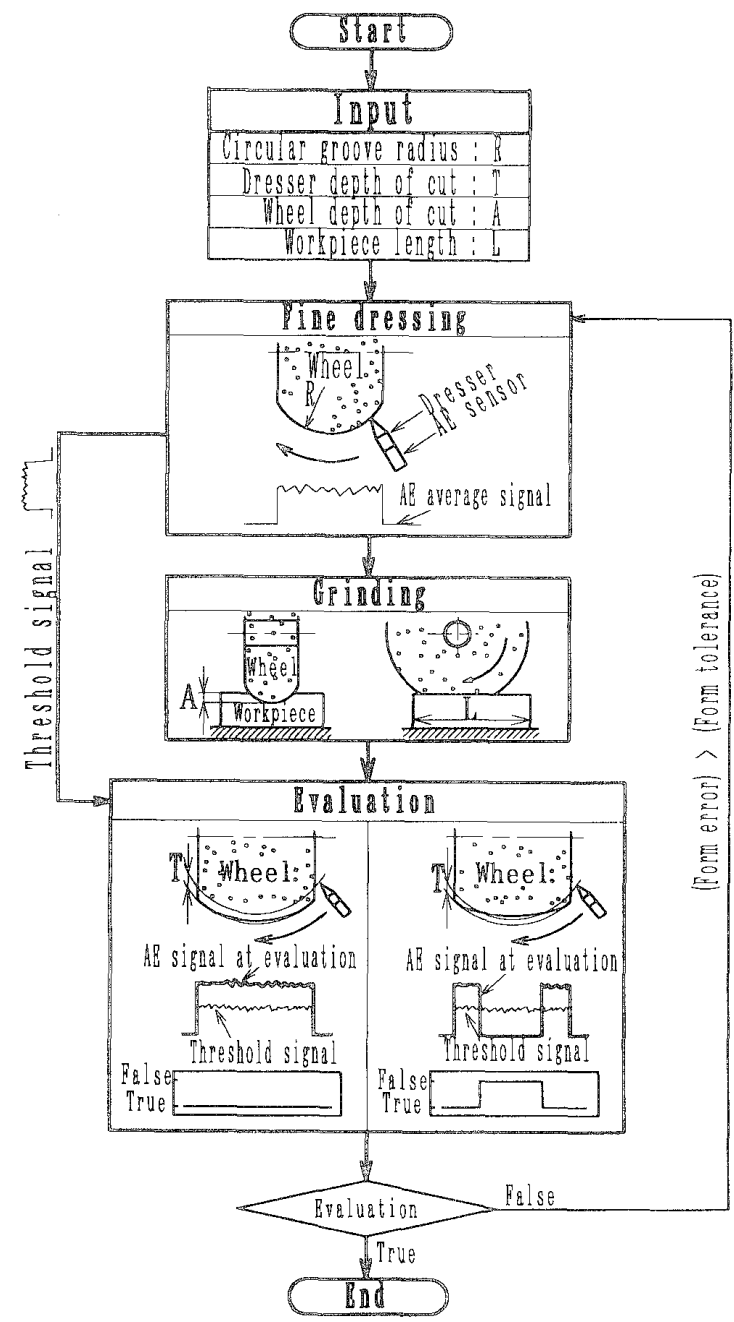

Fig.14 Flow-chart of the workpiece form error compensating cycle

满研削加エで得た結果を示す。この実験では所望の公

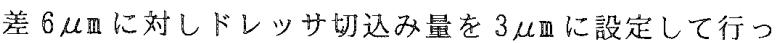
ている。これは図 13(a)に示したように本方法の測定詥

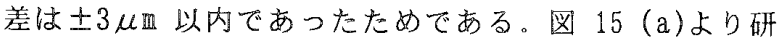
削距離の增加とともに工作物形状誤差は增加し，第一 回目の研削加工ではいずれも公差内に加工し得ていな い。本サイクルはこの形状誤差を最大砥石輪郭摩耗量 より間接測定し，工作物形状誤差が公差内に加工し得 ていないと判断して，第二回目以降の研削加工を行い， 確実に工作物形状誤差を減少させている。図 15(b)は同 様にしてV清研削加工に適用した結果である。この場 合も，研削距離の增加とともに工作物形状誤差が増加 し，第一回目の研削では公差内に加エし得ていない。 本サイクルはこの形状誤差をとら充第二回目以降の研 削加工を行い，確実に工作物形状誤差を減少させてい る。これらのことより，本補正サイクルは総形研削加 エで発生した工作物形状誤差をAE信号を用いて最大砥

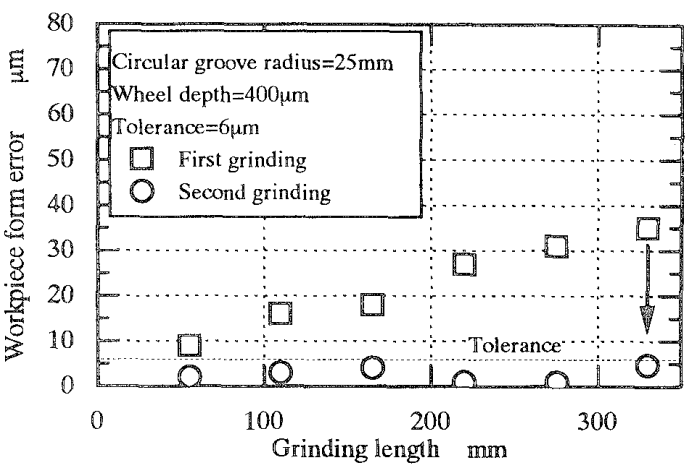

(a) Circular groove grinding

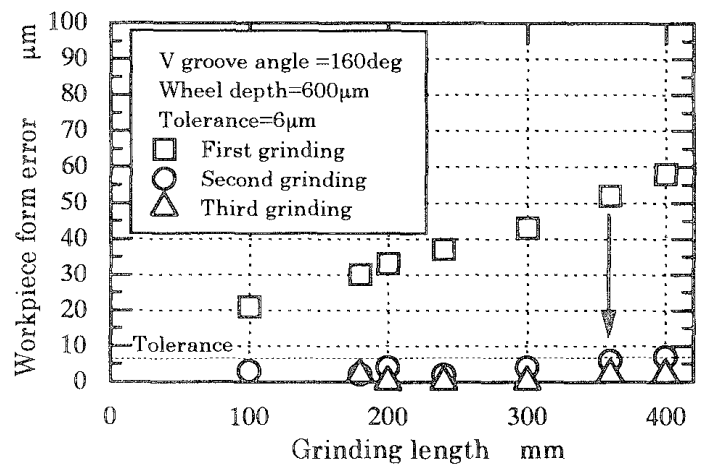

(b) V groove grinding

Fig.15 Decreasing process of workpiece form errors in the proposed cycle

石輪郭摩耗量から間接測定し自動的に補正することが 可能であることを確認できた。

\section{6 。結言}

本研究は $\mathrm{AE}$ センサ付ドレッサを用い NC 研削盤を利 用した総形研削加工における最大砥石輪郭摩耗量の測 定法，工作物形状誤差の間接測定法および工作物形状 誤差補正サイクルを提案し，これらの有用性が実験的 に確認できた。主な結果は以下の通りである。

1) $\mathrm{AE}$ センサ付きドレッサを用いて総形研削加工後の 最大砥石輪郭摩耗量を定量的に測定することができ る。

2) 工作物形状䛊差を最大砥石輸郭摩耗量から間接的に 自動測定する手法の有用性を実験的に示した。

3) 総形研削加工における工作物形状䛊差補正サイクル を提案し，本実験の場合工作物形状䛊差を設定した 公差 6 田以内に加工することができた。

\section{参考文献}

（1）和泉真澄，李和樹，若林忠，井上茂; $A E$ 信号を利 用した砥石摩耗に基づく工作物寸法誤差の測定とそ の補正，機論，63-613，C(1997)，P.334〜339。 